\title{
Russland og flyktningene over Storskog
}

Forholdet til Russland og tilstrømningen av flyktninger fra Nord-Afrika og Midtøsten er blant sakene som har preget europeisk og norsk offentlighet de siste årene. Høsten 2015 ble de to debattene koblet sammen på grensen mellom Norge og Russland. I løpet av få måneder søkte over 5000 mennesker asyl ved grensestasjonen Storskog i Finnmark. Debatten gikk høyt både om flyktningene og om hvorvidt Russland hadde en rolle i å styre flyktningstrømmen mot Norge.

UNHCR anslår at rundt en million mennesker flyktet til Europa i 2015, det store flertallet via landene ved Middelhavet. Europeiske land har fortsatt ikke lykkes i å bli enige om hvordan dette skal håndteres. Frem til september 2015 hadde flyktningene som kom til Norge stort sett måttet reise gjennom mange europeiske land, og flyktningspørsmålet ble først og fremst sett på som et felles europeisk problem. Det var ikke mange som tenkte på at Norges grense mot Russland også er en ytre Schengengrense. Overraskelsen over at flyktningene begynte å komme over Storskog gled over i panikk etter hvert som antallet økte. Norge var rett og slett ikke forberedt på en slik utvikling.

Da flyktningene begynte å ankomme Storskog i store antall, knyttet debatten seg også til den dominerende norske russlandsdiskursen. Forholdet til Russland har gradvis blitt dårligere over tid, og særlig etter Russlands annektering av Krim i 2014 . Mye som har med Russland å gjøre tolkes i lys av oppfatningen av Russland som en trussel. I tillegg forstås russisk politikk ofte som et resultat av en uttenkt plan - det som skjer, skjer fordi Kreml vil det slik. I en slik kontekst ble tilstrømmingen av flyktninger over den norske grensen av flere fortolket som en gjennomtenkt plan fra Russlands side - og flyktningene som et «våpen» i Russlands «hybridkrig» mot Vesten. Begrepet hybridkrig kan i flere sammenhenger være opplysende, men det kan bære galt av sted hvis alt tolkes inn $i$ et potensielt altomfattende «hybridkrigparadigme».

En lignende tendens, med motsatt fortegn, kan finnes i måten flyktningkrisen har blitt tolket på i Russland. I russisk offentlighet har det dominerende perspektivet på flyktningspørsmålet vært at Europa i stor grad kan takke seg selv: USA og Europas militære innblanding i Midtøsten er en hovedårsak til flyktningkrisen og skylden ligger dermed hos Vesten selv. Flyktningkrisen spiller slik på lag med utbredte oppfatninger i Russland om at svært mange av dagens største problemer kan spores til USA med allierte. Felles for disse storpolitiske tenkemåtene er at den menneskelige dimensjonen forsvinner. 
I denne utgaven av Nordisk Østforum ser Arild Moe og Lars Rowe nærmere på hva som skjedde da «den arktiske flyktningruten» ble populær høsten 2015, og hvordan saken ble håndtert av norske og russiske myndigheter. For å undersøke påstanden om at Norge ble «straffet» av Russland, sammenligner forfatterne også situasjonen med den på den finsk-russiske grensen i samme tidsrom. Moe og Rowe konkluderer med at det ikke er rimelig å se på flyktningstrømmen som et resultat av en villet russisk politikk, og mener at den mest sannsynlige forklaringen rett og slett var at «migranter fra ulike deler av verden, med varierende grad av beskyttelsesbehov, ble klar over muligheten for å komme seg til Schengen-området på en billigere og ikke minst mindre risikofylt måte enn tidligere». Forfatterne taler dermed mot et hybridkrig-perspektiv i denne konkrete saken.

Redaksjonen ønsker god lesning, og minner dere også om at Østforums arkiv tilbake til 2002 ligger åpent tilgjengelig på www.tidsskriftet-nof.no.

Kristian Lundby Gjerde og Natalia Moen-Larsen 